\title{
Knowledge Mapping of Platform Research: A Visual Analysis Using VOSviewer*
}

\author{
Xue Ding \\ Department of Business Administration \\ School of Business \\ Nanjing University \\ Nanjing, China
}

\begin{abstract}
Platform is a topic that has been shaped by numerous articles for years. This study makes a contribution by a bibliometric analysis of academic research on platform in management, business and economics areas. The author analyzes 619 articles on platform from the Web of Science database from 1978 to 2018 . Various methods are used to perform the bibliometric analysis: performance analysis and scientific maps. Furthermore, VOSviewer is used to map the bibliographic data. This study shows networks of references, journals and authors, indicating their impacts on the platform's research. The results will enhance understanding of platform research and enable future scholars to focus their own studies effectively.
\end{abstract}

Keywords-platform; bibliometric analysis; co-citations; VOSviewer

\section{INTRODUCTION}

With rapid development of the global markets, competition becomes increasingly fierce. To achieve sustainable competitive advantage, an innovator may choose to "open" its technology by allowing outsiders to participate in its development and commercialization [1], which makes the innovation paradigm has evolved from sole firm's R\&D behavior into cluster's cooperative R\&D behavior [2]. Platform is the very cluster that support multiple interactions across various actors and can facilitate sustainable technical development [3][4][5][6]. As a consequence, firms advocate to build a platform with their various cooperators (such as vendors, customers, governments, intermediary), which results many markets in today's economy are organized around platforms, including mobile and PC operating systems, online games and so on [7]. There are some excellent platform-based companies in China, such as Alibaba and Tencent, both of which are able to obtain sustainable expand in the market because of the platform. The chase of firms towards platform make it a trending topic in academia, and resulting the exponential study rise in this field.

What is a platform? An early definition is that a platform

*Fund: This study is supported by the National Natural Science Foundation of China (grant number 71732002- "Research on Organizational Architecture and Collaborative Management of Leading Enterprises' Innovation Chain"). is a common structure including a set of subsystems and interfaces from which a stream of products can be developed [8]. Bresnahan and Greenstein emphasize the role of a platform in promoting cooperation, and consider it as a bundle of standard components around which buyers and sellers coordinate efforts [9]. Hereafter, a more general and straightaway definition is brought forward, platform is the products and services that integrate groups of users in twosided networks [10]. A platform may encompass physical components, tools and rules to facilitate development, a collection of technical standards to support interoperability, or any combination of these things [4]. There are different kinds of platforms, thus, scholars try to classify it. Gawer and Cusumano classify platform into two categories: internal and external platform [11]. Internal platform is a set of assets organized in a common structure from which a company can efficiently develop and produce a stream of derivative products, which is a firm level definition [8][12]; while external platform is products, services, or technologies that act as a foundation upon which external innovators, organized as an innovative business ecosystem, can develop their own complementary products, technologies, or services [13]. The "network effect" can explain the different value of platforms: the more users who choose the platform, the more valuable the platform becomes to the suppliers, users and owners because of growing access to the network of users and often to a growing set of complementary innovations.

The academia and enterprises studying and practicing platforms has resulted a rapid growth in literature on platform. However, there is a lack of comprehensive, quantitative reviews exclusively focused on platform. Our work in this study provides a thorough and in-depth picture on the status quo of researches in the platform field. We analyze 619 publications on platform from the Web of Science database (WoS) from 1978 to the end of 2018. By analyzing bibliometric indicators achieved on WoS, we illustrate the distribution of publications, most influential journals, most cited publications, most important authors, most outstanding institutions and countries. Furthermore, by analyzing data with VOSviewer, we present the co-citation of cited references, co-citation of authors and co-citation of journals. 
management, business and economics areas. Our study analyzed 619 publications from 1978 to 2018, as the first publication on platform that contains complete information was in 1978 (here we expurgate three anonymous documents in early years).

\section{RESULTS}

This section presents the following results of performance analysis, which includes the descriptive statistics, the distribution of the publications, the most cited publications, the most important authors, the most impact journals, the most influential institutions, and the most outstanding countries in the platform research field. In addition, this section also provides the results of scientific maps. In order to gain an overall perspective of developments in research on platform, we perform the cocitation analysis of references, and authors, journals and their clusters respectively; in order to illustrate the related term in platform research.

\section{A. Performance Analysis}

\section{1) Descriptive statistics}

Through searching and screening, we finally obtained 604 articles and 15 reviews (as we focused on exploring on the intellectual framework of platform research field, we limited publications in article and review categories). The sample in this study were comprised of a total of 619 publications by 741 authors affiliated with 713 institutions in 57 countries, which were published in 228 journals and referred 13,638 references (see "Table I").

TABLE I. DESCRIPTIVE STATISTICS OF THE DATABASE

\begin{tabular}{|l|l|}
\hline \multicolumn{1}{|c|}{ Criteria } & \multicolumn{1}{c|}{ Quantity } \\
\hline Publications & 619 \\
\hline Authors & 1368 \\
\hline Journals & 228 \\
\hline Institutions & 713 \\
\hline Countries & 57 \\
\hline Cited reference & 13638 \\
\hline
\end{tabular}

\section{2) Distribution of publications}

"Fig. 1" shows the chronological distribution of publications in the platform area. The first traceable article was published in 1978, and from then on, the number of publications is on the rise. The growth trend can be divided into three stages. The first stage is from 1978 to 1992, when just one or two articles are published each year, which shows it is embryonic stage. In the subsequent stage, the number of papers produced from 1994 to 2009 reaches more than quadruple of the previous stage, indicating the seedtime timeline. Within the last stage, from 2010 to 2018 , publications meet a considerable increase, which represent blossom in this period. 15,000 journals and 50,000,000 classified publications in 251 categories and 150 research areas [27]. In addition, the WoS is a proper database because it contains a set of data, such as titles, authors, institutions, countries, abstracts, keywords, references, citations count, impact factors and others [28][29]. In order to understand business research on platform, we collected publication information from the WoS Social Science Citation Index (SSCI), and limited to 
platform competition model within two-sided markets, and further analysis the determinants of price allocation and enduser surplus for the two governance structures: for-profit platforms and not-for-profit platforms. The second most cited article Planning for Product Platforms [31] focuses on the product platform. Robertson and Ulrich discuss the four fundamentals of product platform planning: components, processes, knowledge and people and relationships, and advocates a loosely structured platform planning process which focus on the product plan, the differentiation plan and the commonality plan [31]. The third most cited article Constructing Regional Advantage: Platform Policies Based on Related Variety and Differentiated Knowledge Bases [32] introduces a platform approach into the regional advantage constructing issue. By bringing together three notions (related variety, knowledge bases and policy platforms), this study constructs a regional innovation policy model, and implies that the three notions can jointly facilitate economic development within and between regions.

The first most cited article Platform Competition in Twosided Markets [5], accounting for 956 citations, establishes a

TABLE II. Most Cited PublicAtions In The Platform RESEARCH FiELd

\begin{tabular}{|c|c|c|c|c|}
\hline Rank & Title & Journal & Year & $\begin{array}{l}\text { Citations } \\
\text { count }\end{array}$ \\
\hline 1 & Platform competition in two-sided markets & $\begin{array}{l}\text { Journal of The European } \\
\text { Economic Association }\end{array}$ & 2003 & 956 \\
\hline 2 & Planning for product platforms & Sloan Management Review & 1998 & 439 \\
\hline 3 & $\begin{array}{l}\text { Constructing regional advantage: Platform policies } \\
\text { based on related variety and differentiated knowledge } \\
\text { bases }\end{array}$ & Regional Studies & 2011 & 410 \\
\hline 4 & $\begin{array}{l}\text { Internal and external integration for product } \\
\text { development: The contingency effects of uncertainty, } \\
\text { equivocality, and platform strategy }\end{array}$ & Decision Sciences & 2005 & 358 \\
\hline 5 & $\begin{array}{l}\text { How open is open enough? Melding proprietary and } \\
\text { open source platform strategies }\end{array}$ & Research Policy & 2003 & 288 \\
\hline 6 & $\begin{array}{l}\text { The assimilation of knowledge platforms in } \\
\text { organizations: An empirical investigation }\end{array}$ & Organization Science & 2001 & 266 \\
\hline 7 & $\begin{array}{l}\text { Crowd-funding: Transforming customers into investors } \\
\text { through innovative service platforms }\end{array}$ & Journal of Service Management & 2011 & 226 \\
\hline 8 & $\begin{array}{l}\text { Platform evolution: Coevolution of platform } \\
\text { architecture, governance, and environmental dynamics }\end{array}$ & Information Systems Research & 2010 & 212 \\
\hline 9 & Industry platforms and ecosystem innovation & $\begin{array}{l}\text { Journal of Product Innovation } \\
\text { Management }\end{array}$ & 2014 & 204 \\
\hline 10 & Export-platform foreign direct investment & $\begin{array}{l}\text { Journal of the European } \\
\text { Economic Association }\end{array}$ & 2007 & 199 \\
\hline 11 & Technological platforms and diversification & Organization Science & 1996 & 195 \\
\hline 12 & $\begin{array}{l}\text { Electronic word of mouth (eWOM): How eWOM } \\
\text { platforms influence consumer product judgement }\end{array}$ & $\begin{array}{l}\text { International Journal of } \\
\text { Advertising }\end{array}$ & 2009 & 194 \\
\hline 13 & $\begin{array}{l}\text { Real options and IT platform adoption: Implications for } \\
\text { theory and practice }\end{array}$ & Information Systems Research & 2004 & 176 \\
\hline 14 & $\begin{array}{l}\text { The platform organization: Recombining strategies, } \\
\text { structures, and surprises }\end{array}$ & Organization Science & 1996 & 174 \\
\hline 15 & $\begin{array}{l}\text { Open platform strategies and innovation: Granting } \\
\text { access vs. devolving control }\end{array}$ & Management Science & 2010 & 159 \\
\hline 16 & $\begin{array}{l}\text { Options thinking and platform investments: Investing in } \\
\text { opportunity }\end{array}$ & California Management Review & 1994 & 159 \\
\hline 17 & $\begin{array}{l}\text { Bridging differing perspectives on technological } \\
\text { platforms: Toward an integrative framework }\end{array}$ & Research Policy & 2014 & 155 \\
\hline 18 & $\begin{array}{l}\text { Appropriateness and impact of platform-based product } \\
\text { development }\end{array}$ & Management Science & 2001 & 152 \\
\hline 19 & How companies become platform leaders & MIT Sloan Management Review & 2008 & 149 \\
\hline 20 & $\begin{array}{l}\text { Two-sided competition of proprietary vs. open source } \\
\text { technology platforms and the implications for the } \\
\text { software industry }\end{array}$ & Management Science & 2006 & 143 \\
\hline
\end{tabular}




\begin{tabular}{|c|c|c|c|c|}
\hline Rank & Title & Journal & Year & $\begin{array}{c}\text { Citations } \\
\text { count }\end{array}$ \\
\hline 21 & $\begin{array}{l}\text { Platform owner entry and innovation in complementary } \\
\text { markets: Evidence from Intel }\end{array}$ & $\begin{array}{l}\text { Journal of Economics \& } \\
\text { Management Strategy }\end{array}$ & 2007 & 142 \\
\hline 22 & $\begin{array}{l}\text { Options analysis of software platform decisions: A case } \\
\text { study }\end{array}$ & MIS Quarterly & 2000 & 142 \\
\hline 23 & A price theory of multi-sided platforms & American Economic Review & 2010 & 140 \\
\hline 24 & $\begin{array}{l}\text { Co-creation of value in a platform ecosystem: The case } \\
\text { of enterprise software }\end{array}$ & MIS Quarterly & 2012 & 135 \\
\hline 25 & $\begin{array}{l}\text { Platform investments and volatile exchange rates: } \\
\text { Direct investment in the US by Japanese electronic } \\
\text { companies }\end{array}$ & $\begin{array}{l}\text { Review of Economics and } \\
\text { Statistics }\end{array}$ & 1996 & 127 \\
\hline 26 & Platform envelopment & Strategic Management Journal & 2011 & 124 \\
\hline 27 & The elements of platform leadership & MIT Sloan Management Review & 2002 & 121 \\
\hline 28 & $\begin{array}{l}\begin{array}{l}\text { Competitive dynamics: } \\
\text { prospective research platform }\end{array} \\
\end{array}$ & $\begin{array}{l}\text { The Academy of Management } \\
\text { Annals }\end{array}$ & 2012 & 112 \\
\hline 29 & $\begin{array}{l}\text { Perspective: Creating a platform - based approach for } \\
\text { developing new services }\end{array}$ & $\begin{array}{l}\text { Journal of Product Innovation } \\
\text { Management }\end{array}$ & 2001 & 111 \\
\hline 30 & Entry into platform - based markets & Strategic Management Journal & 2012 & 108 \\
\hline 31 & $\begin{array}{l}\text { Platform-driven development of product families: } \\
\text { Linking theory with practice }\end{array}$ & $\begin{array}{l}\text { Journal of Product Innovation } \\
\text { Management }\end{array}$ & 2003 & 103 \\
\hline
\end{tabular}

\section{4) Most important authors}

About $90.21 \%$ of the authors in the sample have published one paper, and $3.07 \%$ of the authors have produced three of more documents. Hence, we analysis the authors who have published three or more papers. Furthermore, considered to the impact of the author, we choose the author whose paper have been cited over 50 times.

According to the result shows in "Table III", with 160.67 citations per publication, Bruce Kogut becomes the most important author. The subsequent authors are Michael Cusumano, Annabelle Gawer, Joel West, Marc Meyer. Nevertheless, the top five authors who publish more are Andrei Hagiu, Annabelle Gawer, Marc Meyer, Amrit Tiwana, Carmelo Cennamo. That means Andrei Hagiu published the most with 9 papers. In consequence, Annabelle Gawer and Marc Meyer are authors who are more productive and influential.

TABLE III. Most Important Authors IN THE PlatForm ReseARCH FiELD

\begin{tabular}{|l|l|l|l|l|}
\hline Rank & \multicolumn{1}{|c|}{ Authors } & Publication & \multicolumn{1}{c|}{ Citations } & \multicolumn{1}{c|}{ Average citation/publication } \\
\hline 1 & Kogut, B & 3 & 482 & 160.67 \\
\hline 2 & Cusumano, M. A & 4 & 487 & 121.75 \\
\hline 3 & Gawer, A & 8 & 865 & 108.13 \\
\hline 4 & West, J & 3 & 313 & 104.33 \\
\hline 5 & Meyer, M. H & 5 & 323 & 64.6 \\
\hline 6 & Huang, P & 3 & 171 & 57 \\
\hline 7 & Wu, D. J & 3 & 171 & 57 \\
\hline 8 & Parker, G & 3 & 150 & 50 \\
\hline 9 & Van Alstyne, M & 3 & 150 & 50 \\
\hline 10 & Tiwana, A & 5 & 248 & 49.6 \\
\hline 11 & Maffatto, M & 3 & 146 & 48.67 \\
\hline 12 & Hagiu, A & 9 & 388 & 43.11 \\
\hline 13 & Peitz, M & 3 & 92 & 30.67 \\
\hline 14 & Huang, G. Q & 3 & 82 & 27.33 \\
\hline 15 & Wright, J & 3 & 71 & 23.67 \\
\hline 16 & Chen, J & 3 & 70 & 23.33 \\
\hline 17 & Zhang, C & 3 & 70 & 23.33 \\
\hline 18 & Evans, D. S & 4 & 81 & 20.25 \\
\hline 19 & Cennamo, C & 4 & 77 & 19.25 \\
\hline 20 & Belleflamme, P & 3 & 51 & 17 \\
\hline 21 & Schmalensee, R & 3 & 50 & 16.67 \\
\hline
\end{tabular}

\section{5) Most impacted journals}

Three or more articles have been published by $33.18 \%$ of journals, and four or more articles have been published by $23.58 \%$ of journals. Hence, we choose journals which have four or more articles. Furthermore, considered to the effect of journals, the following analysis includes journals with at least 50 citations (as shown in "Table IV").
According to the "average citation per publication" indicator, Organization Science is the most impact journal (160 citation per publication), followed by Regional Studies (121.5 citations per publication), Decision Sciences (99.25 citations per publication), MIT Sloan Management Review (84 citations per publication) and Research Policy (80.83 citations per publication). In the contrary, the top five 
Journal of Industrial Organization (13 publications), International Journal of Technology Management (13 publications), MIS Quarterly (13 publications).

TABLE IV. Most Impact JouRnals In THE Platform RESEARCH FIELD

\begin{tabular}{|c|c|c|c|c|}
\hline Rank & Journal & Publications & Citations & Average citation/publication \\
\hline 1 & Organization Science & 4 & 640 & 160 \\
\hline 2 & Regional Studies & 4 & 486 & 121.5 \\
\hline 3 & Decision Sciences & 4 & 397 & 99.25 \\
\hline 4 & MIT Sloan Management Review & 4 & 336 & 84 \\
\hline 5 & Research Policy & 6 & 485 & 80.83 \\
\hline 6 & Strategic Management Journal & 5 & 365 & 73 \\
\hline 7 & Journal of Product Innovation Management & 15 & 749 & 49.93 \\
\hline 8 & Management Science & 12 & 552 & 46 \\
\hline 9 & American Economic Review & 8 & 319 & 39.88 \\
\hline 10 & California Management Review & 6 & 234 & 39 \\
\hline 11 & Journal of Marketing Research & 4 & 127 & 31.75 \\
\hline 12 & Journal of Public Economics & 4 & 121 & 30.25 \\
\hline 13 & MIS Quarterly & 13 & 365 & 28.08 \\
\hline 14 & Research Technology Management & 5 & 129 & 25.8 \\
\hline 15 & Harvard Business Review & 4 & 101 & 25.25 \\
\hline 16 & Information Economics and Policy & 5 & 126 & 25.2 \\
\hline 17 & Information Systems Research & 23 & 562 & 24.43 \\
\hline 18 & Journal of Economics \& Management Strategy & 12 & 285 & 23.75 \\
\hline 19 & Journal of Management Information Systems & 11 & 884 & 21.56 \\
\hline 20 & Tourism Management & 4 & 83 & 20.75 \\
\hline 21 & Technovation & 7 & 131 & 18.71 \\
\hline 22 & Industrial Marketing Management & 4 & 70 & 17.5 \\
\hline 23 & Electronic Commerce Research and Applications & 9 & 154 & 17.11 \\
\hline 24 & $\begin{array}{lllll}\text { International Journal of } & \text { Operations } & \text { Production } \\
\text { Management } & & & & \end{array}$ & 5 & 79 & 15.8 \\
\hline 25 & IEEE Transactions on Engineering Management & 8 & 110 & 13.75 \\
\hline 26 & International Journal of Electronic Commerce & 8 & 106 & 13.25 \\
\hline 27 & European Journal of Operational Research & 6 & 79 & 13.17 \\
\hline 28 & Electronic Markets & 5 & 65 & 13 \\
\hline 29 & International Journal of Industrial Organization & 13 & 152 & 11.69 \\
\hline 30 & Journal of Information Technology & 9 & 98 & 10.89 \\
\hline 31 & Public Choice & 6 & 63 & 10.5 \\
\hline 32 & Journal of Business Research & 8 & 82 & 10.25 \\
\hline 33 & Journal of Industrial Economics & 5 & 50 & 10 \\
\hline 34 & Journal of Marketing & 5 & 50 & 10 \\
\hline 35 & Journal of The Operational Research Society & 5 & 50 & 10 \\
\hline 36 & Journal of Advertising Research & 9 & 81 & 9 \\
\hline 37 & Infornation \& Managemetn & 8 & 70 & 8.75 \\
\hline 38 & International Journal of Technology Management & 13 & 110 & 8.46 \\
\hline 39 & Technological Forecasting and Social Change & 9 & 71 & 7.89 \\
\hline 40 & Journal of Competition Law Economics & 7 & 54 & 7.71 \\
\hline
\end{tabular}

6) Most influential institutions

In the sample, $83.87 \%$ of institutions have published one or two articles, and $90.88 \%$ of institutions have produced one to three articles. Therefore, we choose at least four publications and 50 citations as criteria to extract the most influential institutions in the platform field (as shown in "Table V").

The University of Pennsylvania in the United States is ranked 1 in the platform area (121.25 citations per publication). The subsequent institutions are Imperial College London (The United Kingdom) and Bocconi University (Italy), with the 95.11 and 56.67 citations per publication respectively. Institutions with the more publications are Harvard University (The United States),
MIT (The United States) and Tsinghua University (China) with 19,14 and 13 publications respectively. 
TABLE V. Most InFLUENTIAL InSTITUTIONS In THE PLATFORM RESEARCH FIELD

\begin{tabular}{|c|c|c|c|c|c|}
\hline Rank & Institution & Country & Publications & Citations & $\begin{array}{c}\text { Average } \\
\text { citation/publication }\end{array}$ \\
\hline 1 & University of Pennsylvania & The United States & 8 & 970 & 121.25 \\
\hline 2 & Imperial College London & The United Kingdom & 9 & 856 & 95.11 \\
\hline 3 & Bocconi University & Italy & 6 & 340 & 56.67 \\
\hline 4 & University of Padua & Italy & 4 & 224 & 56 \\
\hline 5 & $\begin{array}{l}\text { Massachusetts Institute of Technology } \\
\text { (MIT) }\end{array}$ & The United States & 14 & 756 & 54 \\
\hline 6 & Michigan State University & The United States & 5 & 270 & 54 \\
\hline 7 & Eindhoven University of Technology & Netherlands & 4 & 182 & 45.5 \\
\hline 8 & Northeastern University & The United States & 6 & 271 & 45.17 \\
\hline 9 & University of Georgia & The United States & 6 & 268 & 44.67 \\
\hline 10 & Tulane University & The United States & 4 & 176 & 44 \\
\hline 11 & The University of Maryland & The United States & 11 & 481 & 43.73 \\
\hline 12 & University of Illinois & The United States & 5 & 214 & 42.8 \\
\hline 13 & Korea University & Korea & 4 & 168 & 42 \\
\hline 14 & Boston University & The United States & 10 & 400 & 40 \\
\hline 15 & Harvard University & The United States & 19 & 743 & 39.11 \\
\hline 16 & Georgia Institute of Technology & The United States & 6 & 224 & 37.33 \\
\hline 17 & INSEAD & France & 5 & 171 & 34.2 \\
\hline 18 & New York University & The United States & 11 & 324 & 29.45 \\
\hline 19 & The University of Hong Kong & China & 4 & 116 & 29 \\
\hline 20 & University of Groningen & Netherlands & 6 & 140 & 23.33 \\
\hline 21 & Northwestern University & The United States & 5 & 116 & 23.2 \\
\hline 22 & Tampere University of Technology & Finland & 4 & 90 & 22.5 \\
\hline 23 & Linkoping University & Sweden & 4 & 82 & 20.5 \\
\hline 24 & University of Oxford & The United Kingdom & 5 & 102 & 20.4 \\
\hline 25 & University of Cambridge & The United Kingdom & 5 & 99 & 19.8 \\
\hline 26 & Stanford University & The United States & 7 & 136 & 19.43 \\
\hline 27 & The University of Chicago & The United States & 5 & 96 & 19.2 \\
\hline 28 & University College London & The United Kingdom & 6 & 108 & 18 \\
\hline 29 & National University Singapore & Singapore & 12 & 203 & 16.92 \\
\hline 30 & University of Toronto & The United States & 4 & 65 & 16.25 \\
\hline 31 & The University of Auckland & New Zealand & 5 & 81 & 16.2 \\
\hline 32 & University of Missouri & The United States & 4 & 63 & 15.75 \\
\hline 33 & University Mannheim & Germany & 7 & 101 & 14.43 \\
\hline 34 & Erasmus University Rotterdam & Netherlands & 5 & 70 & 14 \\
\hline 35 & Stockholm School of Economics & Sweden & 4 & 44 & 13.75 \\
\hline 36 & Catholic University of Leuven & Belgium & 5 & 67 & 13.4 \\
\hline 37 & Fudan University & China & 7 & 91 & 13 \\
\hline 38 & City University of Hong Kong & China & 5 & 61 & 12.2 \\
\hline 39 & Delft University of Technology & Netherlands & 6 & 70 & 11.67 \\
\hline 40 & Aalto University & Finland & 7 & 61 & 8.71 \\
\hline 41 & Tsinghua University & China & 13 & 76 & 5.85 \\
\hline
\end{tabular}

\section{7) Most outstanding countries}

$75.44 \%$ of the countries have published less than 20 papers, and $73.68 \%$ of countries possess less than 300 citations. Hence, we choose countries which have over 20 publications and 300 citations.

From the data shows in "Table VI", the United States is the most impact country in the platform area (31.34 citations per publication). France and Sweden are ranked two and three with 43.61 and 37.75 citations per publication, respectively. Countries with the most publications are the
United States, the United Kingdom and France. Therefore, we can find that, the United States and France are the two countries with both more publications and more citations within platform. 


\section{B. Scientific Maps}

\section{1) Map of cited references}

The original sample was reduced from 619 publications to 75 publications with at least 15 times. On the basis of these 75 most- cited references, this study built the network within the platform research field by co-citation analysis. Results show the 75 references are divided into four clusters, each color stands for a cluster (See "Fig. 2").

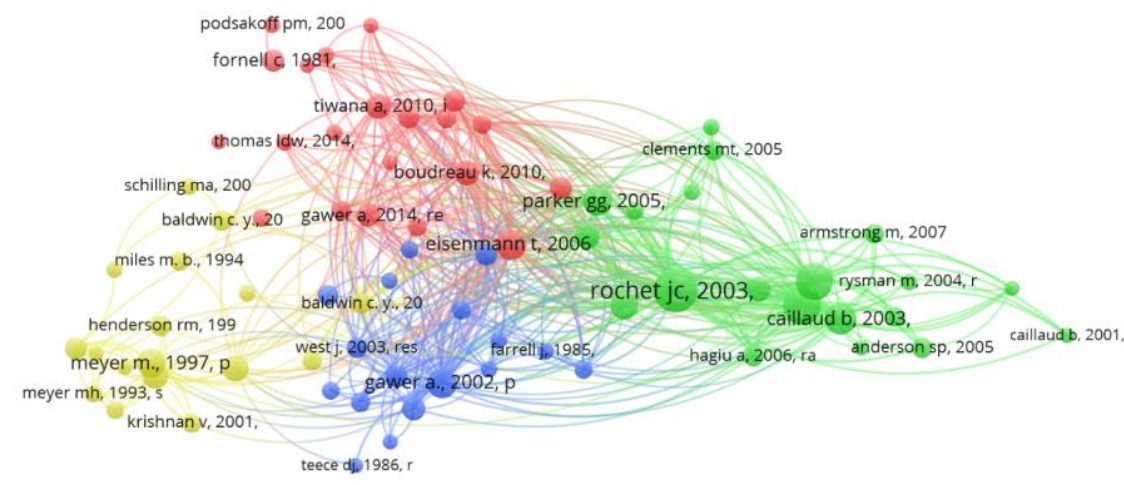

\& vosviewer

Fig. 2. Co-citation of cited references.

The first cluster relates platform to the innovation and change issues. Adner and Kapoor identify that external innovation change will influence the firms' outcome within the platform [34]. Boudreau explores the relationship between different open platform strategies and the rate of innovation change [4].

The second cluster seek to explore the industry-wide platform, studies from Rochet, Armstrong and Weyl reveal network effect of multi-sided markets from economic perspective. Rochet and Tirole establishes a platform competition model within two-sided markets on the basis of network externality [5]. Armstrong and Wright analyses twosided markets when competition exists between two platforms, they introduce "competitive bottlenecks" into the two-sided markets framework [35].

The third part of the cluster analysis relates to open thinking on the platform. West explores the proper strategy for platform, by analyzing the hardware and software company [36]. Chesbrough, Vanhaverbeke and West define open innovation as a paradigm which firm could and should use both internal and external ideas, and internal and external paths to market, and finally advance their technology [2].

Cluster 4 involves research on the product platform topic. Meyer and Lehnerd define the product platform as a set of subsystems and interfaces that form a common structure from which a stream of derivative products can be efficiently developed and produce [8]. Robertson and Ulrich emphasize the importance of planning the product platform for enterprise, and discuss the four fundamentals of product platform planning: components, processes, knowledge and people and relationships, and advocates a loosely structured platform planning process which focus on the product plan, the differentiation plan and the commonality plan [31]. (See "Table VII") 
TABLE VII. CLUSTERs ReSUlTING FROM THE MOST-CITED REFERENCES (PARENTHESIS Is THE NUMBER OF CITATIONS)

\begin{tabular}{|c|c|c|c|}
\hline \multicolumn{2}{|c|}{ Cluster 1 - Innovation and change (521) } & \multicolumn{2}{|c|}{ Cluster 2 - Network effect of multi-sides markets (769) } \\
\hline Eisenmann et al., 2006 & (59) & Rochet \& Tirole, 2003 & (117) \\
\hline Boudreau, 2010 & & Armstrong, $2006 \quad(86)$ & \\
\hline Tiwana et al., 2010 & & Rochet \& Tirole, 2006 & (84) \\
\hline Gawer, 2014 & & Caillaud \& Jullien, 2003 & (63) \\
\hline Boudreau, 2012 & & Parker \& Van Alstyne, 2005 & (53) \\
\hline Fornell \& Larcker, 1981 & (30) & Katz \& Shapiro, 1985 & (49) \\
\hline Ceccagnoli et al., 2012 & (29) & Katz \& Shapiro, 1994 & (39) \\
\hline Gawer \& Cusumano, 2013 & (25) & Rysman, 2009 & \\
\hline Adner \& Kapoor, 2010 & (24) & Anderson, 2005 & \\
\hline Cennamo \& Santalo, 2013 & (22) & Hagiu, 2006 & \\
\hline Parker et al., 2016 & & Clements \& Ohashi, 2005 & (25) \\
\hline Zhu \& Iansiti, 2012 & & Armstrong \& Wright, 2007 & (23) \\
\hline Barney, 1991 & & Weyl, 2010 & \\
\hline Ghazawneh \& Henfridsson, 2013 & (18) & Evans, 2003 & \\
\hline Thomas, 2014 & & Corts \& Lederman, 2009 & (18) \\
\hline Boudreau, 2009 & & Nair, 2004 (18) & \\
\hline Podsakoff et al., 2003 (17) & & Rysman, 2004 & \\
\hline Yoo et al., 2010 & & Caillaud \& Jullien, 2001 & (15) \\
\hline March, 1991 & & Hagiu, 2009 & \\
\hline Shapiro, 1999 & & Kaiser \& Wright, 2006 & (15) \\
\hline Wareham et al., 2014 & (15) & & \\
\hline Cluster 3 - Different types of inno & ovation on the platform (390) & Cluster 4 - Product platform (4 & \\
\hline Gawer \& Cusumano, 2002 & (57) & Meyer \& Lehnerd, 1997 & (50) \\
\hline Gawer \& Cusumano, 2008 & (33) & Eisenhardt, 1989 & \\
\hline Eisenmann et al., 2011 & (31) & Robertson \& Ulrich, 1998 & (42) \\
\hline Gawer \& Henderson, 2007 & (30) & Ulrich, 1995 & \\
\hline West, 2003 & & Baldwin \& Woodard, 2009 & (28) \\
\hline Bresnahan\&Greenstein, 1999 & (25) & Baldwin \& Clark, 2000 & (27) \\
\hline Chesbrough et al., 2006 & (26) & Henderson \& Clark, 1990 & (26) \\
\hline Evans, 2006 & & Miles et al., 1994 & \\
\hline Economides \& Katsamakas, 200 & (21) & Krishnan \& Ulrich, 2001 & (23) \\
\hline Iansiti \& Levien, 2004 & (21) & Cusumano \& Gawer, 2002 & (22) \\
\hline Shapiro et al., 1998 & & Meyer, 1993 & \\
\hline Von Hippel, 2005 & & Sawhney, 1998 & \\
\hline Eisenmann et al., 2009 & (17) & Gawer, 2009 & \\
\hline Farrel\& Saloner, 1985(17) & & Sanchez \& Mahoney, 1996 & (17) \\
\hline Katz \& Shapiro, 1986 (17) & & Schilling, 2000 & \\
\hline Teece, 1986 & & Baldwin \& Clark, 1997 & (16) \\
\hline Jacobides et al., 2006 (15) & & Meyer et al., 1997 & \\
\hline
\end{tabular}

2) Map of most cited authors

With the minimum 40 citations, the sample was declined to a new sample which contains 40 authors, and has 3078 citations in total. This study portrayed the map of the 40 authors consisting of four clusters by co-citation analysis of authors (See "Fig. 3").

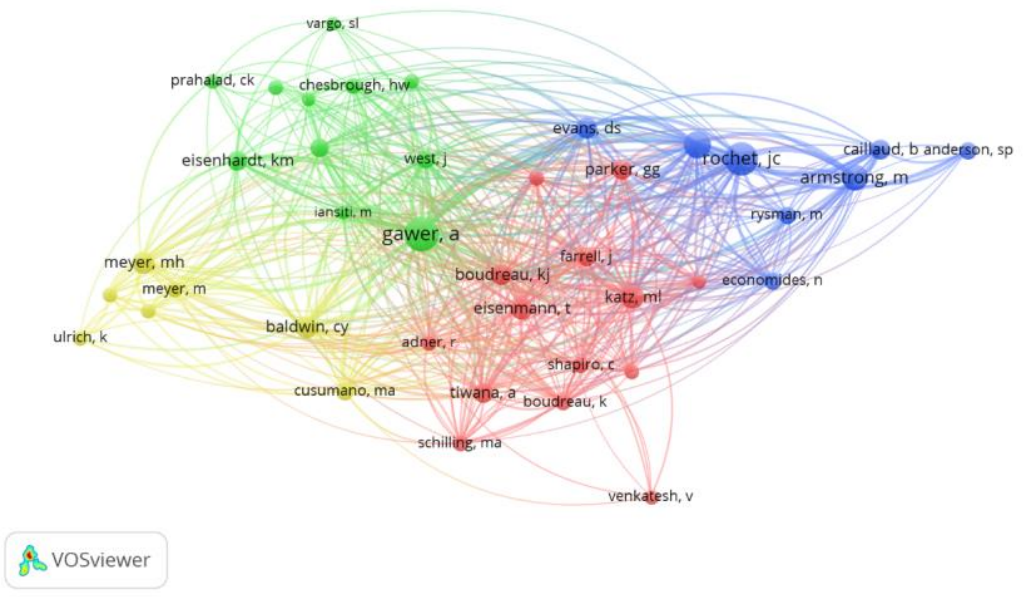

Fig. 3. Co-citation of cited authors. 
Bernard Caillaud, Andrei Hagiu), networks (e.g. Nicholas Economides), most of whom study on economic quantity relationships by constructing economic mathematical model.

Cluster 4 has the least authors with the lowest number of citations in total (469). Nevertheless, this cluster also includes studies from various fields, like modularity (e.g. Carliss Baldwin), leadership (e.g. Michael Cusumano), product platform (e.g. Marc Meyer, David Robertson).

3) Map of most cited journals

By employing the threshold at 120 citations, we got a set of 36 journals that are used for co-citation analysis of cited journals, and finally gained a network consists of management, economics, marketing and information system four clusters (See "Fig. 4").
Cluster 3 includes two-sided markets (e.g. Mark Armstrong, Jean-Charles Rochet), pricing theory (e.g.

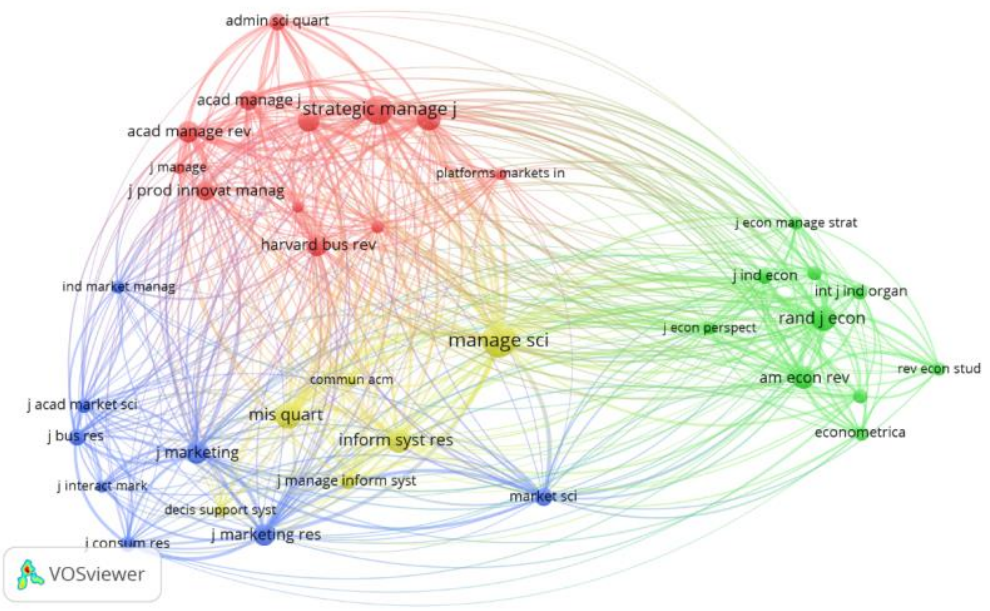

Fig. 4. Co-citation of cited journals.

The management cluster contains journals concentrating on strategic management (Strategic Management Journal), management practice (Harvard Business Review) and theoretic and empirical researchers on management (Journal of Management, Academy of Management Review, Academy of Management Journal).

The economics cluster basically includes journals that accept microeconomics which focus on the organization level (RAND Journal of Economics, Journal of Economics \& Management Strategy), economectrics (Econometrica) and industrial economics focusing on the industry level (International Journal of Industrial Organization).

The marketing cluster encompasses journals that focus on consumer behavior (Journal of Consumer Research), marketing research practice and marketing theory (Journal of Marketing Research) and electronic, interactive and direct marketing environments (Journal of Interactive Marketing).

The information system cluster is an emerging field which is more relevant with platform research that other clusters. This cluster involves journals which publish study on platform (Information System Research), information technology (Decision Support Systems) and ecosystem (MIS Quarterly).

\section{CONCLUSION}

This study achieves some insights from the literature review and summarizes the existing studies. By employing the performance analysis which obtained on WoS, this study identified the most cited articles, the most important authors, the most impact journals, the most influential institutions and the most outstanding countries in the field of platform. This study identified the most cited publications by counting the number of citations. The first most cited article "Platform competition in two-sided markets", which was written by Rochet and Tirole. As with the most important authors, this study uses two indicators to identify: Hagiu is the most productive author who published nine articles, while Kogut is the most influential author with the highest average citation per publication.

The journal that published the most articles is Information Systems Research, which suggests that this journal is more interesting in the platform topic. The journal with the highest citation per publication is Organization Science, which represent the most impact status in the platform research field. The countries that published most are the United States, the United Kingdom and France, and 
[14] Rey-Martí, A.; Ribeiro-Soriano, D.; Palacios-Marqués, D. A Bibliometric Analysis of Social Entrepreneurship. J. Bus. Res. 2016 69(5), 1651-1655.

[15] Small, H. Co-citation in the Scientific Literature: A New Measure of the Relationship between Two Documents. J. Am. Soc. Inf. Sci. 1973, 24(4), 265-269.

[16] Albort-Morant, G.; Ribeiro-Soriano, D. A Bibliometric Analysis of International Impact of Business Incubators. J. Bus. Res. 2016, 69(5), 1775-1779.

[17] Bellis, N. D. Bibliometrics and Citation Analysis: From the Science Citation Index to Cybermetrics. Scarecrow Press: Lanham, ME, USA, 2009; pp. 8-10.

[18] Noyons, E. C.; Moed, H. F.; Luwel, M. Combining Mapping and Citation Analysis for Evaluative Bibliometric Purposes: A Bibliometric Study. J. Am. Soc. Inf. Sci. 1999, 50(2), 115-131.

[19] Thelwall, M. Bibliometrics to Webometrics. J. Inf. Sci. 2008, 34(4), 605-621.

Through bibliometric analyses, this study is helpful for portraying a comprehensive framework of platform research, and enabling future scholars to focus their own studies effectively. However, we have to acknowledge that this study also has limitations. First, the sample in our study is captured in only one database. Although WoS encompass various journals, it could not cover the whole journals on the platform topic. Second, this work uses two types of publications (articles and reviews). Future study can extend data collection to other types of publications, which may provide more insights and latest findings in the platform field. Finally, although the bibliometric analysis by employing specialized software is objective, the following interpretation of the results is somewhat subjective.

\section{REFERENCES}

[1] Shapiro, C.; Carl, S.; Varian, H. R. Information rules: A Strategic Guide to the Network Economy. Harvard Business Press: Boston, MA, USA, 1998; pp. 19-36.

[2] Chesbrough, H.; Vanhaverbeke, W.; West, J. Open innovation: Researching a New Paradigm. Oxford University Press on Demand: New York, NY, USA, 2006; pp. 2-14.

[3] Parker, G. G.; Van Alstyne, M. W. Two-sided Network Effects: A Theory of Information Product Design. Manage. Sci. 2005, 51(10), 1494-1504.

[4] Boudreau, K. Open Platform Strategies and Innovation: Granting Access vs. Devolving Control. Manage. Sci. 2010, 56(10), 1849-1872.

[5] Rochet, J. C.; Tirole, J. Platform Competition in Two-sided Markets. J. Euro. Econ. Assoc. 2003, 1(4), 990-1029.

[6] Weyl, E. G. A Price Theory of Multi-sided Platforms. Am. Econ. Rev. 2010, 100(4), 1642-1672.

[7] Rochet, J. C.; Tirole, J. Two-sided Markets: A Progress Report. The RAND. J. Econ. 2006, 37(3), 645-667.

[8] Meyer, M. H.; Lehnerd, A. P. The Power of Product Platforms. The Free Press, New York, NY, USA, 1997; pp.3-20.

[9] Bresnahan, T. F.; Greenstein, S. Technological Competition and the Structure of the Computer Industry. J. Ind. Econ. 1999, 47(1), 1-40.

[10] Eisenmann, T.; Parker, G.; Van Alstyne, M. W. Strategies for Twosided Markets. Harvard. Bus. Rev. 2006, 84(10), 92-103.

[11] Gawer, A.; Cusumano, M. A. Industry Platforms and Ecosystem Innovation. J. Prod. Innov. Manage. 2014, 31(3), 417-433.

[12] Muffatto, M.; Roveda, M. Product Architecture and Platforms: A Conceptual Framework. Int. J. Technol. Manage. 2002, 24(1), 1-16.

[13] Gawer, A.; Cusumano, M. A. Platform Leadership: How Intel, Microsoft, and Cisco Drive Industry Innovation. Harvard Business School Press: Boston, MA, USA, 2002; pp. 29-30.
[20] Cobo, M. J.; López-Herrera, A. G.; Herrera-Viedma, E.; Herrera, F. Science Mapping Software Tools: Review, Analysis, and Cooperative Study among Tools. J. Am. Soc. Inf. Sci. Tech. 2011, 62(7), 13821402.

[21] Klavans, R.; Boyack, K. W. Identifying a Better Measure of Relatedness for Mapping Science. J. Am. Soc. Inf. Sci. Tech. 2006, 57(2), 251-263.

[22] White, H. D.; Mccain, K. W. Visualizing a Discipline: An Author Cocitation Analysis of Information Science. J. Am. Soc. Inf. Sci. 1998, 49, 1972-1995.

[23] McCain, K. W. Mapping Economics Through the Journal Literature: An Experiment in Journal Cocitation Analysis. J. Am. Soc. Inf. Sci. 1991, 42(4), 290-296.

[24] Danvila-del-Valle, I.; Estévez-Mendoza, C.; Lara, F. J. Human Resources Training: A Bibliometric Analysis. J. Bus. Res. 2019, 101, 627-636.

[25] Cardona, G.; Sanz, J. Publication Analysis of the Contact Lens Field: What are the Current Topics of Interest? J. Optom. 2015, 8(1), 33-39.

[26] Vallaster, C.; Kraus, S.; Lindahl, J. M. M.; Nielsen, A. Ethics and Entrepreneurship: A Bibliometric Study and Literature Review. J. Bus. Res. 2019, 99, 226-237.

[27] Merigó, J. M.; Yang, J. B. A Bibliometric Analysis of Operations Research and Management Science. Omega. 2017, 73, 37-48.

[28] Carvalho, M.M.; Fleury, A.; Lopes, A.P. An Overview of the Literature on Technology Roadmapping (TRM): Contributions and Trends. Technol. Forecast. Soc. 2013, 80, 1418-1437.

[29] Gaviria-Marin, M.; Merigó, J. M.; Baier-Fuentes, H. Knowledge Management: A Global Examination Based on Bibliometric Analysis. Technol. Forecast. Soc. 2019, 140, 194-220.

[30] Koufteros, X.; Vonderembse, M.; Jayaram, J. Internal and External Integration for Product Development: The Contingency Effects of Uncertainty, Equivocality, and Platform Strategy. Decision Sci. 2005, 36(1), 97-133.

[31] Robertson, D.; Ulrich, K. Planning for Product Platforms. MIT Sloan Manage. Rev. 1998, 39(4), 19-31

[32] Asheim, B. T.; Boschma, R.; Cooke, P. Constructing Regional Advantage: Platform Policies Based on Related Variety and Differentiated Knowledge Bases. Regional Studies. 2011, 45(7), 893 904.

[33] Dzikowski, P. A Bibliometric Analysis of Born Global Firms. J. Bus. Res. 2018, 85, 281-294.

[34] Adner, R.; Kapoor, R. Value Creation in Innovation Ecosystems: How the Structure of Technological Interdependence Affects Firm Performance in New Technology Generations. Strategic Manage. J. 2010, 31(3), 306-333.

[35] Armstrong, M.; Wright, J. Two-sided Markets, Competitive Bottlenecks and Exclusive Contracts. Econo. Theory. 2007, 32(2), 353-380.

[36] West, J. How Open is Open Enough? Melding Proprietary and Open Source Platform Strategies. Res. Policy. 2003, 32(7), 1259-1285. 